\title{
Inherited Mitochondrial Disease
}

James Davison, Hugh Lemonde, Shamima Rahman*

*author for correspondence

James Davison FRCPCH PhD is a Consultant in Paediatric Metabolic Medicine at Great Ormond Street Hospital NHS Foundation Trust, London UK.

Hugh Lemonde ARCS, MRCPCH, PhD is a Consultant in Paediatric Metabolic Medicine at the Evelina Children's Hospital, London UK.

Shamima Rahman FRCP FRCPCH PhD is Professor of Paediatric Metabolic Medicine in the Mitochondrial Research Group, Genetics and Genomic Medicine Programme, UCL Institute of Child Health, London, UK and Honorary Consultant in Paediatric Metabolic Medicine at Great Ormond Street Hospital NHS Foundation Trust, London UK.

\section{Correspondence to:}

Professor Shamima Rahman

Mitochondrial Research Group

Genetics and Genomic Medicine

UCL Great Ormond Street Institute of Child Health

London WC1N 1EH, UK.

Telephone: $+44(0) 2079052608$

shamima.rahman@ucl.ac.uk 


\section{Abstract}

Inherited disorders that affect mitochondrial function are a diverse group of conditions with different pathophysiological mechanisms and highly variable clinical phenotypes. Paediatric patients may present with a defined clinical syndrome or, more commonly, with non-specific signs of mitochondrial disease. Recognition of mitochondrial disease relies on having a high index of suspicion when faced with a multisystem disorder of unclear aetiology, in addition to knowledge of the various defined mitochondrial clinical syndromes. Evidence of mitochondrial dysfunction should be sought from a variety of organ systems using both functional and biochemical testing. Recent advances in genomic technology are changing the approach to diagnosis. Treatment of mitochondrial disease requires multi-disciplinary supportive management to address multi-systemic features. Disease specific therapies are available for a small number of conditions, and a number of novel therapies are under evaluation.

Key words: $\quad$ Mitochondrial disease, Diagnosis, Multiorgan, Investigation, Treatment 


\section{$\underline{\text { Introduction }}$}

Mitochondria are ubiquitous intracellular organelles that are fundamental to cellular physiology. Mitochondria are double membrane-bound structures housing many enzyme systems that are integrated closely with cytosolic biochemical processes.

The process of oxidative phosphorylation results in the generation of adenosine triphosphate (ATP) by ATP synthase (complex V), driven by the proton electrochemical gradient generated by the preceding complexes (I-IV) of the respiratory chain. Thus mitochondria are critical in cellular energy production, but also support many other diverse cellular functions and homeostasis, including cellular signalling and control of apoptosis.

Mitochondria exist in varying numbers depending on cell type, and form a network of interconnecting organelles. A notable exception is the erythrocyte that lacks mitochondria. Tissues with high energy requirements such as muscle myocytes or neurons have higher numbers of mitochondria.

The more than 1500 structural and functional proteins that make up mitochondria are encoded by genes in the main nuclear deoxyribonucleic acid (DNA), and also in the unique mitochondrial DNA (mtDNA). mtDNA is a $16.5 \mathrm{~kb}$ circular DNA molecule that contains 37 genes encoding 13 mitochondrial proteins and 24 ribonucleic acid (RNA) species.

Inherited disorders of mitochondrial function can arise if any of the nuclear or mtDNA genes carry mutations, with clinical disorders associated with at least 300 nuclear genes and all of the mtDNA genes (see Figure 1). Nuclear gene defects are inherited in a Mendelian fashion with both dominant and recessive, and autosomal and X-linked patterns. mtDNA mutations are only inherited matrilineally, since mitochondria are only inherited from the ovum and not the sperm. 
Each cell contains many hundreds or thousands of copies of the mtDNA molecule, and any given cell can contain both normal and mutated mtDNA (mtDNA heteroplasmy). If the proportion of mutated mtDNA surpasses a threshold, clinical problems can manifest from the resulting mitochondrial dysfunction. There is a great clinical heterogeneity seen for any given mtDNA mutation, since the heteroplasmy level of mutant mtDNA will differ between individuals and between tissues in any one individual.

Primary defects of mitochondrial function may affect the respiratory chain function directly, mtDNA replication and translation, respiratory chain cofactor synthesis, protein/solute import and/or mitochondrial membrane structure and function (Figure 1). Secondary mitochondrial dysfunction has been implicated in a variety of disease states such as Alzheimer and Huntingdon diseases, cancer and also in the aging process. This article will focus on primary inherited conditions of mitochondrial dysfunction.

\section{When to suspect mitochondrial disease}

The diverse nature of mitochondrial disease leads to a significant diagnostic challenge. Crucial to the recognition of mitochondrial disease is its multisystem nature, which may lead to several organ systems being affected. Examples of these clinical features are summarised in Table 1.

While many patients have a non-specific combination of symptoms (non-syndromic forms), there are a number of specific clinical syndromes (Table 2) whose recognition can expedite diagnosis. However, the majority of paediatric patients investigated for mitochondrial disease do not fall into the syndromic category. The presence of unexplained lactic acidosis often leads to the consideration of mitochondrial disease, but lactate is neither a sensitive nor specific marker of mitochondrial disease. 
Obtaining a family history is important in the investigation of inherited metabolic disease, and mitochondrial disease is no exception. However, any pattern of inheritance can be observed in mitochondrial disease. Disorders resulting from defects in genes encoded in the nuclear genome can be inherited as autosomal recessive or dominant or X-linked traits, while disorders of the mitochondrial genome may be maternally inherited or be sporadic. The degree of mtDNA heteroplasmy may be correlated with clinical phenotype, for example the m.8993T $>\mathrm{G}$ mutation causes NARP (late onset neuropathy, ataxia and retinitis pigmentosa) at moderately high heteroplasmy ( 70\%-90\% of mutated mtDNA) while at very high mutant loads (typically $>90 \%$ ) causes infantile encephalopathy (maternally inherited Leigh syndrome). The inheritance of mtDNA from ovum to embryo is poorly understood, but a genetic bottleneck causes the degree of heteroplasmy passed from the mother to offspring to be unpredictable.

\section{Defined clinical syndromes}

A comprehensive list of all known mitochondrial syndromes is not within the scope of this article. Some examples of the more common syndromes presenting in childhood, those with different pathological mechanisms and those conditions whose diagnosis will alter management are described below. A broader list of clinical syndromes can be seen in Table 2 .

\section{Leigh Syndrome}

Leigh and Leigh-like syndromes (subacute necrotising encephalomyelopathy) are probably the most commonly recognised mitochondrial disorders in childhood. Usually presenting in the first year of life, neurological features such as psychomotor retardation, dystonia, ophthalmoplegia and ataxia predominate, variably accompanied by systemic features such as faltering growth, anaemia, cardiomyopathy and diarrhoea. The disorder commonly has a relapsing and remitting neurological 
course, although some patients may remain stable for many years whilst others display a rapid progressive deterioration. The characteristic changes in the brain comprise focal, bilateral and symmetrical lesions in the basal ganglia, thalamus, brain stem and posterior columns of the spinal cord (Figure 2). Originally a post mortem pathological diagnosis, characteristic neuroimaging features on MRI scans are now the mainstay of diagnosis, together with a typical clinical history and elevated lactate levels in blood and/or cerebrospinal fluid (CSF).

The aetiology of Leigh syndrome is heterogeneous and includes various enzyme deficiencies, including defects of respiratory chain complexes I and IV, pyruvate dehydrogenase (PDH), biotinidase, Coenzyme $\mathrm{Q}_{10}\left(\mathrm{CoQ}_{10}\right)$ biosynthesis and numerous mtDNA mutations (most frequently in genes encoding subunits of complex I and complex V). A significant proportion of those that have complex IV (cytochrome $c$ oxidase, COX) deficiency have mutations in SURF1, a nuclear-encoded gene responsible for the assembly of COX and the most common nuclear cause of Leigh syndrome. Inheritance of Leigh syndrome may be maternal (mtDNA mutations), autosomal recessive (e.g. SURF1 deficiency) or X-linked recessive (e.g. PDH deficiency), so without a definitive genetic diagnosis genetic counselling is challenging.

\section{Mitochondrial DNA depletion syndrome (MDDS)}

A number of different clinical syndromes result from a deficiency of mtDNA replication or repair, all of which are caused by defects of nuclear genes. The diagnostic hallmark of these conditions is reduced mtDNA copy number in muscle or liver. It is most commonly associated with a hepatocerebral syndrome presenting with neonatal/infantile liver failure, hypoglycaemia, global developmental delay and seizures and includes the well described Alpers-Huttenlocher syndrome. Numerous causative genes have been described including POLG (encoding the catalytic subunit of DNA polymerase gamma), TWNK (encoding the twinkle DNA helicase), DGUOK, MPV17 and SUCLG1, all involved in mtDNA maintenance, replication or repair. Navajo neurohepatopathy presents with hepatopathy, 
leukoencephalopathy and peripheral neuropathy and is caused by deficiency of MPV17. Other MDDS include encephalomyopathy with mild methylmalonic aciduria (SUCLA2), encephalomyopathy caused by $R R M 2 B$ mutations (frequently accompanied by prominent renal involvement) and a progressive myopathy that can mimic spinal muscular atrophy (TK2).

\section{Barth Syndrome}

Barth syndrome is an example of a mitochondrial disorder caused by an abnormality of the mitochondrial membrane. Classical presentation is in the infantile period with cardiomyopathy and associated features such as cyclical neutropaenia, myopathy and dysmorphic features. The defective enzyme (encoded by the TAZ gene) is responsible for membrane lipid remodelling and diagnosis is made by analysis of cardiolipin species.

\section{Pearson Syndrome}

Pearson syndrome, otherwise known as marrow-pancreas syndrome, commonly presents with a significant transfusion-dependent pancytopaenia in infancy. Associated features include pancreatic exocrine insufficiency, enteropathy, renal tubular dysfunction, faltering growth and liver dysfunction. Mortality in infancy is high and children surviving the infantile period invariably develop a progressive neurological/multisystem disorder known as Kearns-Sayre syndrome (see Table 2). Both conditions are caused by mtDNA deletions/rearrangements that are usually sporadic in nature.

\section{Reversible mitochondrial disease}

Two rare mitochondrial conditions are particularly noteworthy owing to their spontaneously reversible nature. Defects in the TRMU gene, responsible for post-transcriptional modification of 
mitochondrial tRNAs, cause acute infantile liver failure that spontaneously resolves after approximately 4 months, however a significant proportion of cases will require liver transplantation. If the acute period is survived, a good prognosis is reported without subsequent neurological progression. 'Benign' reversible myopathy is caused by m.14674T>C/G mutations in the mtDNA MTTE gene encoding the tRNA for glutamate. Patients present in the first few weeks of life with a progressive severe myopathy that may require assisted ventilated for up to 18 months. An almost complete recovery is seen by 2-3 years of age with good prognosis.

\section{Primary coenzyme $Q_{10}$ deficiencies}

Disorders of $\mathrm{CoQ}_{10}$ biosynthesis are rare causes of mitochondrial disease that are potentially treatable with $\mathrm{CoQ}_{10}$ replacement therapy. They are clinically heterogeneous with diverse features such as infantile encephalopathy with nephropathy, juvenile cerebellar ataxia, steroid resistant nephrotic syndrome, rhabdomyolysis and myopathy. Diagnosis is often suspected upon specific complex deficiencies I+III/II+III (see diagnosis section) and confirmed by measurement of $\mathrm{CoQ}_{10}$ in peripheral blood mononuclear cells or muscle.

\section{Diagnosis of mitochondrial disease}

The diagnosis of a suspected mitochondrial disorder requires cumulative evidence from clinical, biochemical and radiological investigations, and ultimately elucidating the specific genetic basis of the disease. An obstacle to the diagnosis of mitochondrial disease is the lack of specific biomarkers which, in part, is due to the diverse pathophysiology of mitochondrial disease. If mitochondrial disease is suspected, a stepwise approach to diagnosis is warranted. 
Clinical evaluation should be undertaken as detailed in Table 1 looking for evidence of multisystem disease. Reassessment over time is essential as mitochondrial conditions may evolve, becoming more apparent and involving new organ systems.

Specific biochemical testing should be undertaken including lactate, plasma amino acids, acylcarnitines, urine organic acids and creatine kinase. Elevated lactate is commonly observed in mitochondrial disease, but may be artefactual owing to sampling difficulty. Raised plasma alanine is present in genuine hyperlactataemia and is not seen as an artefact, but neither normal lactate nor normal alanine levels definitively exclude the possibility of mitochondrial disease. Plasma or bloodspot acylcarnitine analysis may identify other causes of lactic acidaemia such as long chain fatty acid oxidation defects. Urine organic acid analysis can identify elevated lactate and other metabolites such as Krebs cycle intermediates or ethylmalonic acid which are non-specific markers of mitochondrial dysfunction. 3-Methylglutaconic aciduria is present in Barth syndrome, and methylmalonic aciduria may be seen in SUCLA2 deficiency and related disorders.

Most paediatric patients suspected of having mitochondrial disease do not have a specific clinical syndrome or biochemistry that points toward to a particular molecular diagnosis and further investigation is therefore needed. Previously this would routinely include invasive muscle biopsy for histology and enzymatic analysis of the respiratory chain enzymes (RCEs). However, with the advent of next generation sequencing, the need for a muscle biopsy may be avoided in some situations. If undertaken, muscle biopsy should be carried out in a specialist centre due to specific requirements of sample handling and the complexity of the enzyme assays. It should also be noted that a general anaesthetic is required for invasive procedures such as muscle biopsy and although there is a theoretical risk of metabolic decompensation following anaesthesia, such events are extremely rare. The tissue of choice is usually skeletal muscle although other sources include liver and cardiac muscle.

Analysis of RCE activity may reveal a single complex deficiency, suggesting a defect of a complex subunit or assembly factor that will guide further molecular testing. Patterns of multiple deficiencies 
may also guide further investigation; deficiency of complex I, III and IV (and V) is suggestive of a defect of mtDNA maintenance or translation or large mtDNA deletion (complex II is spared as only encoded by nuclear genes) while a combined deficiency of $\mathrm{I}+\mathrm{III} / \mathrm{II}+\mathrm{III}$ is suggestive of a $\mathrm{CoQ}_{10}$ deficiency. However none of these rules is universally upheld; almost any pattern of enzyme deficiency may be observed with many of the gene defects known to cause mitochondrial disease. Associated disorders of pyruvate metabolism can be evaluated by assaying pyruvate dehydrogenase (PDH) and pyruvate carboxylase (PC) activity in cultured skin fibroblasts.

Histopathological investigation of tissue also plays an important role. Evidence of mitochondrial proliferation can be seen as ragged red fibres with the modified Gomori trichrome stain, or as ragged blue fibres with the combined COX/succinate dehydrogenase (SDH) stain. The COX stain may reveal fibres deficient in specific enzyme activity (Figure 3).

Confirmation of a molecular genetic diagnosis may be sought from nuclear or mitochondrial genomes, the majority of mitochondrial disease in children being caused by nuclear gene defects. The relatively small mitochondrial genome can be fully sequenced or specific point mutations sought, while large deletions/duplications are detected by Southern blotting or long-range PCR. The MDDS syndromes are associated with a reduced copy number of the mitochondrial genome that can be assessed by quantitative PCR from an affected tissue. Targeted nuclear gene sequencing of a few genes (e.g. POLG, SURF1) is common practice based on clinical, histological and biochemical findings; however the advent of next generation whole exome and whole genome sequencing has enabled diagnosis with an untargeted approach in many cases.

\section{$\underline{\text { Treatment }}$}

Effective clinical treatment for mitochondrial disease requires a multidisciplinary approach to address the many different clinical manifestations. While symptomatic management is still the mainstay of 
treatment, there is an increasing evidence base for specific therapies and a number of novel therapeutic approaches are in the research pipeline. Table 1 highlights some of the different multisystem supportive treatments.

Readily treatable disorders should be identified so that treatment can be initiated, including use of riboflavin (vitamin B2) in ACAD9 or FLAD1 deficiency, biotin for biotinidase deficiency, and CoQ $_{10}$ supplements for the $\mathrm{CoQ}_{10}$ biosynthetic disorders. Arginine therapy in MELAS syndrome is used in the acute management of stroke-like episodes and to prevent further episodes.

Some drugs are known to be detrimental to patients with mitochondrial disease and should be avoided, including sodium valproate (especially in patients with POLG mutations) and some anaesthetic agents including barbiturates and prolonged use of propofol.

A range of novel therapies is in development. Anti-oxidants have been used for a long time to treat patients with mitochondrial disease, since there is an imbalance of mitochondrial redox status with excessive reactive oxygen species. As well as vitamins $\mathrm{C}$ and $\mathrm{E}$ and their chemical analogues, other potential modulators of mitochondrial redox status including EPI-743 and KH176 are currently being evaluated.

Other novel therapies include those that aim to stimulate mitochondrial biogenesis (for example bezafibrate and resveratrol), replacement of nucleosides in selected disorders of mitochondrial nucleoside salvage, and gene therapy approaches such as allotopic gene expression therapies (i.e. recoding mtDNA-encoded genes to be expressed from the nuclear genome).

\section{Summary}

Mitochondrial disorders are a diverse group of conditions with a broad clinical phenotype with the potential to affect any organ system. Unexplained multisystem disease should always alert the 
clinician to the possibility of a mitochondrial disorder; however clinicians should also be aware of classical single organ presentation of disease such as optic atrophy (Leber hereditary optic neuropathy). Investigation of mitochondrial disease is difficult owing to the lack of specific biomarkers and frequently necessitates a multidisciplinary approach. Very few disease specific treatments are available, and novel therapeutic approaches are still under evaluation. The mainstay of treatment remains effective multidisciplinary and multisystem supportive management.

Despite difficulties in diagnosis and treatment, recent advances are rapidly increasing our understanding of mitochondrial disease. The availability of exome sequencing in the clinical setting has led to an increasing number of children with undefined mitochondrial diseases receiving specific genetic diagnoses.

\section{Practice points:}

- Consider mitochondrial disease in multisystem disorders of unknown aetiology.

- Reassessment is important to assess disease progression and the development of multisystem involvement.

- Knowledge of the different defined clinical syndromes is important to aid diagnosis.

- No specific or sensitive biochemical tests exist to aid the diagnosis of mitochondrial disease, so evidence of dysfunction should be sought from a variety of organ systems.

- Genetic diagnosis may be achieved but invasive testing including muscle biopsy may still be required.

- The mainstay of therapy is support of affected organ systems and symptom control.

- Consider early referral to a specialist metabolic team for evaluation and treatment. 
Table 1 - Signs and symptoms of mitochondrial disease classified by organ system, potential investigations and evaluations required and supportive interventions/treatments.

\begin{tabular}{|c|c|c|c|}
\hline Organ system & Signs and Symptoms & $\begin{array}{l}\text { Investigations/ } \\
\text { Evaluations }\end{array}$ & $\begin{array}{l}\text { Interventions/ } \\
\text { Treatments }\end{array}$ \\
\hline Systemic & $\begin{array}{l}\text { Faltering growth, } \\
\text { irritability }\end{array}$ & Growth parameters & \\
\hline Nervous system & $\begin{array}{l}\text { Encephalopathy, } \\
\text { seizures, dystonia } \\
\text { (hypo/hypertonia), } \\
\text { developmental delay } \\
\text { +/-regression, stroke- } \\
\text { like episodes, } \\
\text { migraine, peripheral } \\
\text { neuropathy }\end{array}$ & $\begin{array}{l}\text { Neuroimaging. } \\
\text { Electroencephalogram } \\
\text { (EEG). } \\
\text { Nerve conduction } \\
\text { studies, } \\
\text { electromyography. }\end{array}$ & $\begin{array}{l}\text { Anticonvulsants } \\
\text { Arginine (stroke like } \\
\text { episodes in MELAS) }\end{array}$ \\
\hline Audiological & $\begin{array}{l}\text { Sensorineural hearing } \\
\text { loss }\end{array}$ & $\begin{array}{l}\text { Audiological } \\
\text { assessment. Speech and } \\
\text { language evaluation. }\end{array}$ & $\begin{array}{l}\text { Hearing aids, } \\
\text { cochlear implant }\end{array}$ \\
\hline Ophthalmological & $\begin{array}{l}\text { Pigmentary } \\
\text { retinopathy, } \\
\text { cataracts, ptosis, } \\
\text { progressive external } \\
\text { ophthalmoplegia, } \\
\text { optic atrophy, } \\
\text { nystagmus, } \\
\end{array}$ & $\begin{array}{l}\text { Ophthalmological } \\
\text { review. } \\
\text { Visual evoked } \\
\text { potentials/ } \\
\text { electroretinogram. }\end{array}$ & $\begin{array}{l}\text { Brow suspension } \\
\text { Visual aids }\end{array}$ \\
\hline Muscular & $\begin{array}{l}\text { Myopathy, } \\
\text { rhabdomyolysis }\end{array}$ & Electromyography. & $\begin{array}{l}\text { Physiotherapy, } \\
\text { appropriate mobility } \\
\text { aids and supports }\end{array}$ \\
\hline Gastrointestinal/Liver & $\begin{array}{l}\text { Liver } \\
\text { dysfunction/failure, } \\
\text { hepatomegaly, } \\
\text { enteropathy, } \\
\text { diarrhoea, exocrine } \\
\text { pancreatic } \\
\text { insufficiency, } \\
\text { dysmotility, pseudo- } \\
\text { obstruction }\end{array}$ & $\begin{array}{l}\text { Faecal elastase (exocrine } \\
\text { pancreas function). } \\
\text { Hepatic ultrasound. } \\
\text { Liver function tests. } \\
\text { Assessment of swallow. } \\
\text { Growth monitoring. }\end{array}$ & $\begin{array}{l}\text { Gastrostomy } \\
\text { Enteral feeds } \\
\text { Consider parenteral } \\
\text { nutrition } \\
\text { Consider hepatic } \\
\text { transplant if isolated } \\
\text { liver disease } \\
\text { Pancreatic enzyme } \\
\text { supplementation }\end{array}$ \\
\hline Cardiac & $\begin{array}{l}\text { Cardiomyopathy } \\
\text { (most commonly } \\
\text { hypertrophic), } \\
\text { conduction defects }\end{array}$ & $\begin{array}{l}\text { Electrocardiogram, } \\
\text { echocardiogram }\end{array}$ & $\begin{array}{l}\text { Pacing, implantable } \\
\text { defibrillator } \\
\text { Medical treatment } \\
\text { (Lisinopril, beta } \\
\text { blockers) } \\
\text { Consider cardiac } \\
\text { transplant } \\
\end{array}$ \\
\hline Renal & $\begin{array}{l}\text { Tubulopathy, } \\
\text { nephritis, nephrotic } \\
\text { syndrome (especially } \\
\text { steroid resistant, a }\end{array}$ & $\begin{array}{l}\text { Tubular function assays } \\
\text { (urine NAG/creatinine } \\
\text { and RBP/creatinine). } \\
\text { Albumin/creatinine. }\end{array}$ & $\begin{array}{l}\text { Electrolyte } \\
\text { supplementation } \\
\text { Consider renal } \\
\text { replacement therapy }\end{array}$ \\
\hline
\end{tabular}




\begin{tabular}{|l|l|l|l|}
\hline & $\begin{array}{l}\text { feature of primary } \\
\text { coenzyme } Q_{10} \\
\text { deficiency), } \\
\text { progressive renal } \\
\text { impairment }\end{array}$ & Renal function tests. & \\
\hline Endocrine & $\begin{array}{l}\text { Diabetes mellitus, } \\
\text { growth hormone } \\
\text { insufficiency, } \\
\text { hypoadrenalism, } \\
\text { hypothyroidism, } \\
\text { hypoparathyroidism, } \\
\text { multiple hormone } \\
\text { deficiencies }\end{array}$ & $\begin{array}{l}\text { Growth parameters } \\
\text { Hormone assays (growth } \\
\text { hormone, thyroid, } \\
\text { parathyroid, adrenal } \\
\text { function), blood glucose, } \\
\text { HbA1c. }\end{array}$ & $\begin{array}{l}\text { Appropriate hormone } \\
\text { supplementation } \\
\text { Insulin or oral } \\
\text { antidiabetic agents }\end{array}$ \\
\hline Cutaneous/ hair & $\begin{array}{l}\text { Hypertrichosis, pili } \\
\text { torti (some complex III } \\
\text { assembly defects) }\end{array}$ & Histology. & $\begin{array}{l}\text { Full blood count and } \\
\text { Sideroblastic } \\
\text { anaemia, } \\
\text { pancytopaenia, } \\
\text { neutropaenia, } \\
\text { thrombocytopaenia, } \\
\text { marrow failure }\end{array}$ \\
\hline Haematological & film. & $\begin{array}{l}\text { Transfusion } \\
\text { Iron/ haematinics }\end{array}$ \\
\hline
\end{tabular}


Table 2 - Examples of syndromic mitochondrial disorders

\begin{tabular}{|c|c|c|c|}
\hline Syndrome & Clinical Features & Age of onset & Pathophysiology \\
\hline $\begin{array}{l}\text { Leigh syndrome } \\
\text { (see text) }\end{array}$ & $\begin{array}{l}\text { Developmental delay, } \\
\text { extrapyramidal symptoms, often } \\
\text { progressive }\end{array}$ & $\begin{array}{l}\text { Neonatal/infancy, } \\
\text { late variants exist }\end{array}$ & $\begin{array}{l}\text { Multiple, often } \\
\text { associated with complex } \\
\text { I or IV deficiencies }\end{array}$ \\
\hline $\begin{array}{l}\text { MDDS (see text), } \\
\text { including Alpers- } \\
\text { Huttenlocher } \\
\text { syndrome }\end{array}$ & $\begin{array}{l}\text { Hepatic failure, seizures, } \\
\text { myopathy }\end{array}$ & Neonatal/infancy & $\begin{array}{l}\text { Deficiency of mtDNA } \\
\text { replication/repair }\end{array}$ \\
\hline Barth (see text) & $\begin{array}{l}\text { Cardiomyopathy, myopathy, } \\
\text { cyclical neutropaenia, } \\
\text { dysmorphism }\end{array}$ & Neonatal/infancy & $\begin{array}{l}\text { Mitochondrial } \\
\text { membrane remodelling } \\
\text { disorder (TAZ) }\end{array}$ \\
\hline $\begin{array}{l}\text { Pearson (see } \\
\text { text) }\end{array}$ & $\begin{array}{l}\text { Sideroblastic anaemia, faltering } \\
\text { growth, enteropathy, exocrine } \\
\text { pancreatic dysfunction }\end{array}$ & Infancy & $\begin{array}{l}\text { Large mtDNA deletion } \\
\text { (sporadic) }\end{array}$ \\
\hline $\begin{array}{l}\text { Reversible } \\
\text { mitochondrial } \\
\text { disease (see } \\
\text { text) }\end{array}$ & $\begin{array}{l}\text { Severe reversible myopathy or } \\
\text { reversible liver failure }\end{array}$ & Neonatal/infancy & $\begin{array}{l}\text { Abnormality of } \\
\text { mitochondrial tRNA or } \\
\text { its processing (m.14674 } \\
\mathrm{T}>\mathrm{C}, \mathrm{TRMU})\end{array}$ \\
\hline $\begin{array}{l}\mathrm{CoQ}_{10} \text { deficiency } \\
\text { (see text) }\end{array}$ & $\begin{array}{l}\text { Diverse - encephalopathy, } \\
\text { cerebellar ataxia, steroid } \\
\text { resistant nephrotic syndrome, } \\
\text { rhabdomyolysis }\end{array}$ & $\begin{array}{l}\text { Neonatal to } \\
\text { adulthood }\end{array}$ & $\begin{array}{l}\text { Deficiency of Coenzyme } \\
\mathrm{Q}_{10} \text { biosynthesis - } \\
\text { multiple genes }\end{array}$ \\
\hline MERRF & $\begin{array}{l}\text { Myoclonic Epilepsy with Ragged } \\
\text { Red Fibres. Progressive } \\
\text { encephalopathy, myopathy, } \\
\text { ataxia and myoclonus. } \\
\text { Deafness/optic atrophy }\end{array}$ & Childhood & $\begin{array}{l}\text { mtDNA mutations, most } \\
\text { commonly m.8344G>A }\end{array}$ \\
\hline Kearns-Sayre & $\begin{array}{l}\text { Progressive external } \\
\text { ophthalmoplegia, pigmentary } \\
\text { retinopathy, cardiac conduction } \\
\text { defects and ataxia }\end{array}$ & Before 20 years & $\begin{array}{l}\text { Large mtDNA deletion } \\
\text { (sporadic) }\end{array}$ \\
\hline MELAS & $\begin{array}{l}\text { Mitochondrial } \\
\text { Encephalomyopathy, Lactic } \\
\text { Acidosis, Stroke-like episodes. } \\
\text { Period of normal development, } \\
\text { migraines, myopathy, seizures } \\
\text { and neurological decline. }\end{array}$ & Childhood & $\begin{array}{l}\text { Mostly mtDNA } \\
\text { mutations (m.3243A>G), } \\
\text { also nuclear genes (e.g. } \\
P O L G)\end{array}$ \\
\hline MNGIE & $\begin{array}{l}\text { Mitochondrial Neuro-Gastro- } \\
\text { Intestinal Encephalopathy. } \\
\text { Diverse GI symptoms including } \\
\text { episodic pseudo-obstruction, } \\
\text { peripheral neuropathy, } \\
\text { leukoencephalopathy. }\end{array}$ & Childhood/adulthood & $\begin{array}{l}\text { Mutations of thymidine } \\
\text { phosphorylase (TYMP) }\end{array}$ \\
\hline NARP & $\begin{array}{l}\text { Neuropathy, Ataxia, Retinitis } \\
\text { Pigmentosa. Also seizures, } \\
\text { intellectual impairment/ } \\
\text { dementia. }\end{array}$ & $\begin{array}{l}\text { Childhood to early } \\
\text { adulthood }\end{array}$ & $\begin{array}{l}\text { mtDNA mutation } \\
\text { (m.8993T }>\mathrm{G} / \mathrm{C})\end{array}$ \\
\hline
\end{tabular}




\begin{tabular}{|c|c|c|c|}
\hline Sengers & $\begin{array}{l}\text { Congenital cataracts, } \\
\text { cardiomyopathy, lactic acidosis }\end{array}$ & Neonatal & $\begin{array}{l}\text { Abnormal mitochondrial } \\
\text { membranes and import } \\
\text { in acylglycerol kinase } \\
\text { deficiency (AGK) }\end{array}$ \\
\hline $\begin{array}{l}\text { Ethylmalonic } \\
\text { encephalopathy }\end{array}$ & $\begin{array}{l}\text { Ethylmalonic aciduria, } \\
\text { encephalopathy, acrocyanosis, } \\
\text { petechiae, diarrhoea }\end{array}$ & Infancy & $\begin{array}{l}\text { Disorder of } \\
\text { mitochondrial suphite } \\
\text { detoxification (ETHE1) } \\
\end{array}$ \\
\hline GRACILE & $\begin{array}{l}\text { Growth Retardation, } \\
\text { Aminoaciduria, Cholestasis, Iron } \\
\text { overload, Lactic acidosis and } \\
\text { Early death. }\end{array}$ & Neonatal/infancy & $\begin{array}{l}\text { Isolated complex III } \\
\text { deficiency caused by } \\
\text { impaired assembly } \\
\text { (BCS1L) }\end{array}$ \\
\hline $\begin{array}{l}\text { Leber hereditary } \\
\text { optic } \\
\text { neuropathy } \\
\text { (LHON) }\end{array}$ & $\begin{array}{l}\text { Subacute painless visual loss. } \\
\text { Males }>\text { female } 4: 1 . \text { Occasional } \\
\text { cardiac and/or neurological } \\
\text { involvement }\end{array}$ & $\begin{array}{l}\text { Late childhood to } \\
\text { early adulthood }\end{array}$ & $\begin{array}{l}\text { Three common mtDNA } \\
\text { mutations: } \mathrm{m} .3460 \mathrm{G}>\mathrm{A} \text {, } \\
\text { m.11778G }>\mathrm{A} \text {, } \\
\mathrm{m} .14484 \mathrm{~T}>\mathrm{C}\end{array}$ \\
\hline MLASA & $\begin{array}{l}\text { Myopathy, Lactic Acidosis, } \\
\text { Sideroblastic Anaemia }\end{array}$ & Early childhood & $\begin{array}{l}\text { Mitochondrial DNA } \\
\text { translation defect (e.g. } \\
\text { YARS2 mitochondrial } \\
\text { aminoacyl } \\
\text { tRNA synthetase and } \\
\text { PUS1 tRNA pseudo- } \\
\text { uridinylation) }\end{array}$ \\
\hline
\end{tabular}


Figures

Figure 1 Different components of mitochondrial function can be affected to cause mitochondrial disease. Salient examples of nuclear and mitochondrial DNA genes associated with clinical mitochondrial disease are shown in the figure.

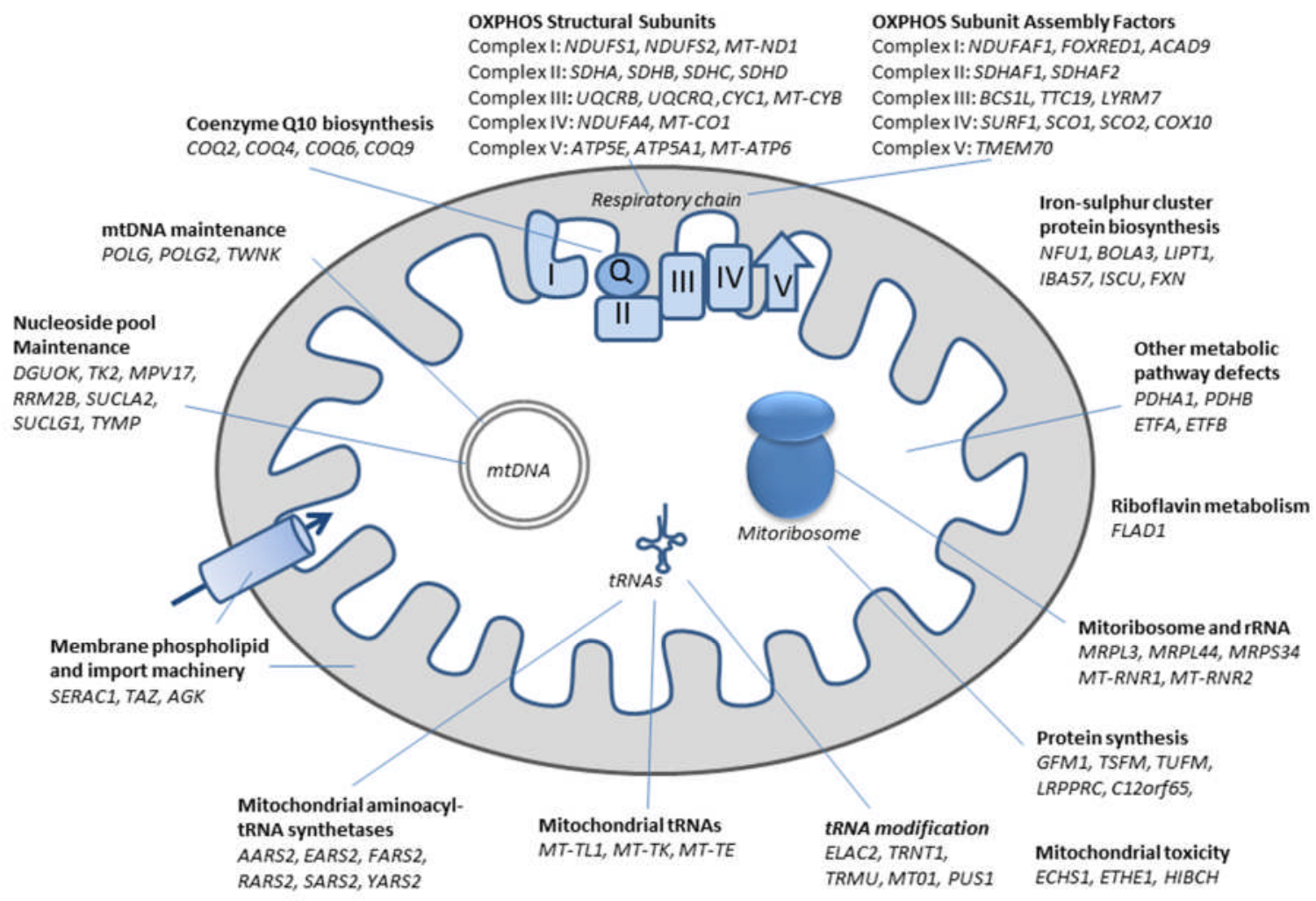


Figure 2 - An axial T2 weighted MRI image including basal ganglia and thalami from a patient with Leigh syndrome. Focal, symmetrical and hyperintense lesions can clearly be seen (white arrows). Signal change could also be seen throughout the brain stem.

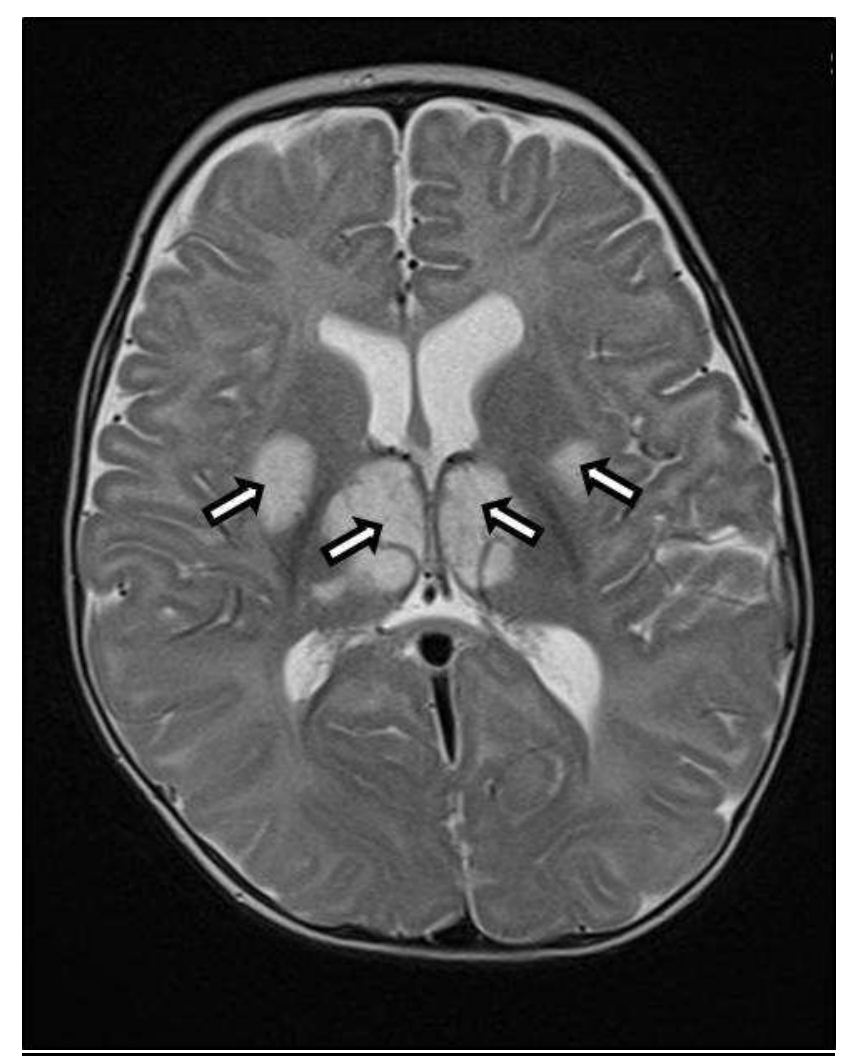


Figure 3 - Histopathology of mitochondrial disease - a) Modified Gomori trichrome stain showing Ragged Red Fibres; b) SDH stain showing SDH-positive fibres; c) COX stain on normal muscle d) COX deficient muscle. (images $a$ and $b$ courtesy of Dr Thomas Jacques)

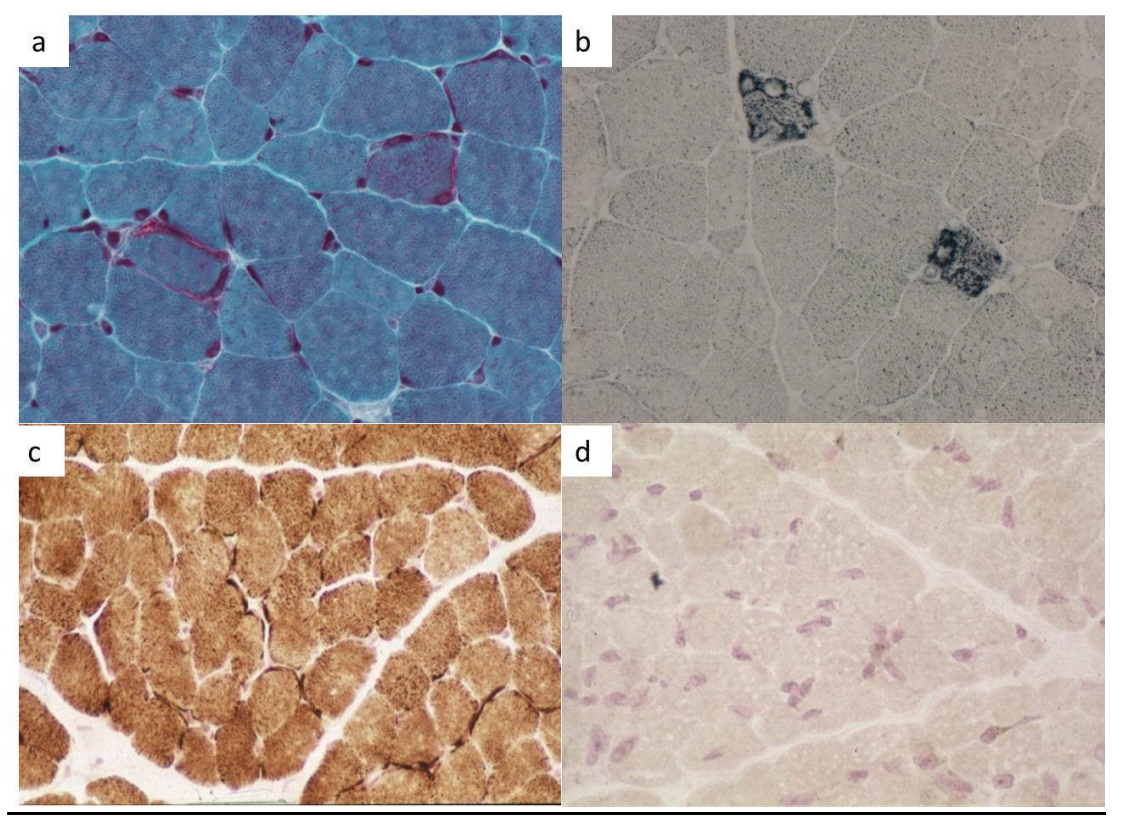


Broomfield A, Sweeney MG, Woodward CE, Fratter C, Morris AM, Leonard JV, Abulhoul L, Grunewald S, Clayton PT, Hanna MG, Poulton J, Rahman S. Paediatric single mitochondrial DNA deletion disorders: an overlapping spectrum of disease. J Inherit Metab Dis. 2015 May;38(3):44557. doi: 10.1007/s10545-014-9778-4. Epub 2014 Oct 29. PubMed PMID: 25352051; PubMed Central PMCID: PMC4432108.

Clarke SL, Bowron A, Gonzalez IL, Groves SJ, Newbury-Ecob R, Clayton N, Martin RP, TsaiGoodman B, Garratt V, Ashworth M, Bowen VM, McCurdy KR, Damin MK, Spencer CT, Toth MJ, Kelley RI, Steward CG. Barth syndrome. Orphanet J Rare Dis 2013;8:23. doi: 10.1186/1750-1172-823.

Davison JE, Rahman S. Nuclear genetic causes of Leigh and Leigh-like syndrome. In: Saneto RP, Parikh S, Cohen BH, eds. Mitochondrial case studies: underlyingmechanisms and diagnosis. London: Elsevier, 2016:113-26.

Davison, J.E. and S. Rahman, Recognition, investigation and management of mitochondrial disease. Arch Dis Child 2017;102:1082-1090.

El-Hattab AW, Craigen WJ, Scaglia F. Mitochondrial DNA maintenance defects. Biochim Biophys Acta. 2017 Jun;1863(6):1539-1555. doi: 10.1016/j.bbadis.2017.02.017. Epub 2017 Feb 16. Review. PubMed PMID: 28215579.

Friedman JR, Nunnari J. Mitochondrial form and function. Nature 2014;505(7483):335-43. Horvath R, Kemp JP, Tuppen HA, Hudson G, Oldfors A, Marie SK, Moslemi AR, Servidei S, Holme E, Shanske S, Kollberg G, Jayakar P, Pyle A, Marks HM, Holinski-Feder E, Scavina M, Walter MC, Coku J, Günther-Scholz A, Smith PM, McFarland R, Chrzanowska-Lightowlers ZM, Lightowlers RN, Hirano M, Lochmüller H, Taylor RW, Chinnery PF, Tulinius M, DiMauro S. Molecular basis of infantile reversible cytochrome c oxidase deficiency myopathy. Brain. 2009 Nov;132(Pt 11):316574. doi: 10.1093/brain/awp221. Epub 2009 Aug 31. PubMed PMID: 19720722; PubMed Central PMCID: PMC2768660.

Kanabus M, Heales SJ, Rahman S. Development of pharmacological strategies for mitochondrial disorders. Br J Pharmacol 2014;171(8):1798-817.

Keshavan N, Rahman S. Natural history of mitochondrial disorders: a systematic review. Essays Biochem. 2018 Jul 6. pii: EBC20170108. doi: 10.1042/EBC20170108. [Epub ahead of print] Review. PubMed PMID: 29980629.

Koga Y, Povalko N, Nishioka J, Katayama K, Yatsuga S, Matsuishi T. Molecular pathology of MELAS and L-arginine effects. Biochim Biophys Acta. 2012 May;1820(5):608-14. doi:

10.1016/j.bbagen.2011.09.005. Epub 2011 Sep 14. Review. PubMed PMID: 21944974.

Lane N, Martin W. The energetics of genome complexity. Nature 2010;467(7318):929-34. Nunnari J, Suomalainen A. Mitochondria: in sickness and in health. Cell 2012;148(6):1145-59. Rahman J, Rahman S. Mitochondrial medicine in the omics era. Lancet 2018; 391: 2560-74 Rahman S, Blok RB, Dahl HH, Danks DM, Kirby DM, Chow CW, Christodoulou J, Thorburn DR. Leigh syndrome: clinical features and biochemical and DNA abnormalities. Ann Neurol 1996;39(3):34351.

Rahman S, Clarke CF, Hirano M. 176th ENMC International Workshop: diagnosis and treatment of coenzyme $Q_{10}$ deficiency. Neuromuscul Disord 2012 ;22(1):76-86.

Rahman S, Poulton J. Diagnosis of mitochondrial DNA depletion syndromes. Arch Dis Child 2009;94(1):3-5.

Rahman S. Gastrointestinal and hepatic manifestations of mitochondrial disorders. J Inherit Metab Dis 2013;36(4):659-73 
Rötig a, Bourgeron T, Chretien D, Rustin P, Munnich a. Spectrum of mitochondrial DNA rearrangements in the Pearson marrow-pancreas syndrome. Hum Mol Genet 1995 ;4(8):1327-30. Thorburn DR, Rahman S. Mitochondrial DNA-Associated Leigh Syndrome and NARP. 2003 Oct 30. In: Pagon RA, Adam MP, Ardinger HH, Bird TD, Dolan CR, Fong CT, Smith RJH, Stephens K, editors. GeneReviews ${ }^{\circledR}$. Seattle (WA): University of Washington, Seattle; 1993-2014.

Vafai SB, Mootha VK. Mitochondrial disorders as windows into an ancient organelle. Nature 2012;491(7424):374-83.

Wedatilake Y, Brown R, McFarland R, Yaplito-Lee J, Morris AA, Champion M, Jardine PE, Clarke A, Thorburn DR, Taylor RW, Land JM, Forrest K, Dobbie A, Simmons L, Aasheim ET, Ketteridge D, Hanrahan D, Chakrapani A, Brown GK, Rahman S. SURF1 deficiency: a multi-centre natural history study. Orphanet J Rare Dis 2013;8(1):96.

Zeharia A, Shaag A, Pappo O, Mager-Heckel AM, Saada A, Beinat M, Karicheva O, Mandel H, Ofek $\mathrm{N}$, Segel R, Marom D, Rötig A, Tarassov I, Elpeleg $\mathrm{O}$. Acute infantile liver failure due to mutations in the TRMU gene. Am J Hum Genet 2009;85(3):401-7. 


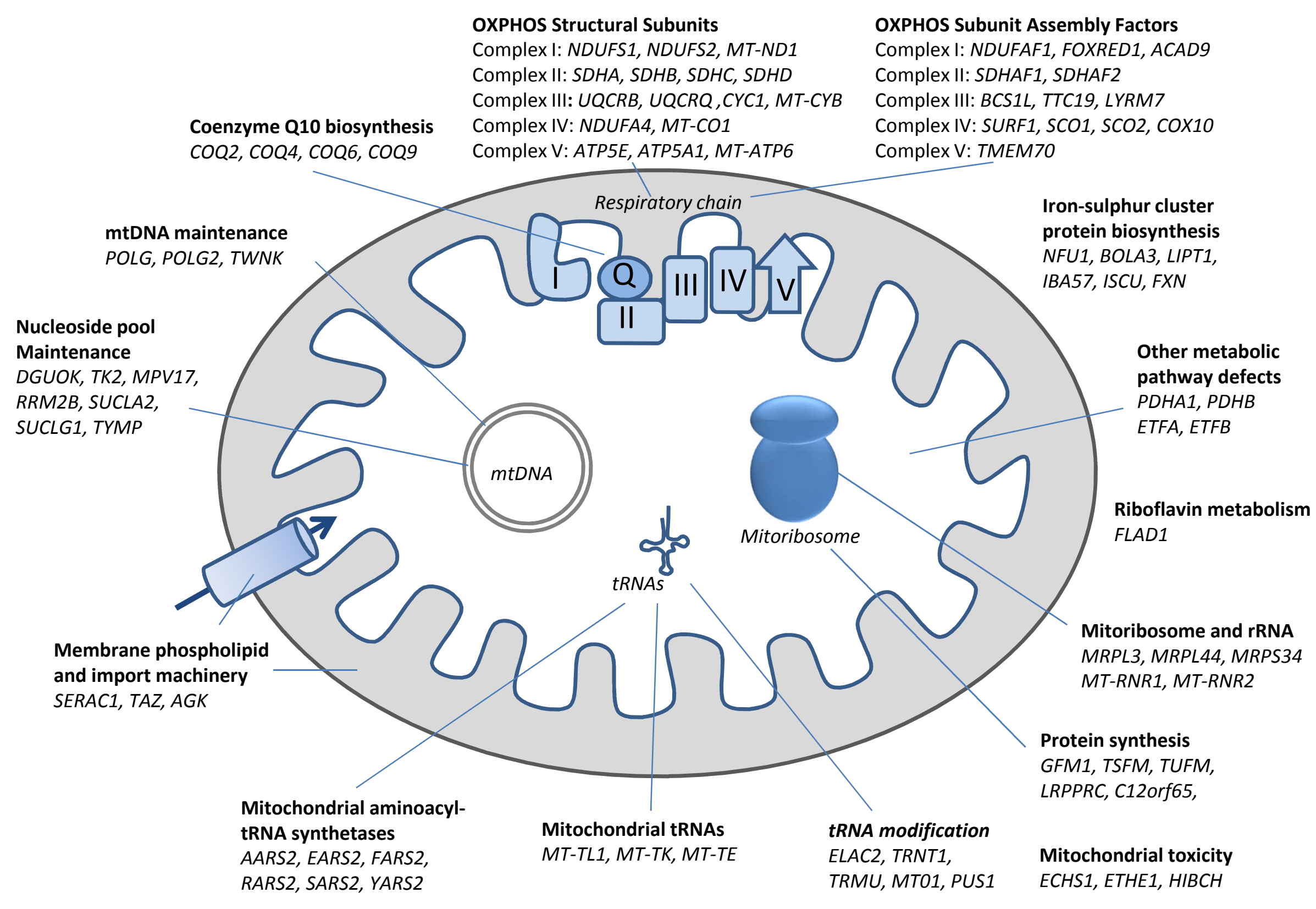


Se:2

Im:12

[R]

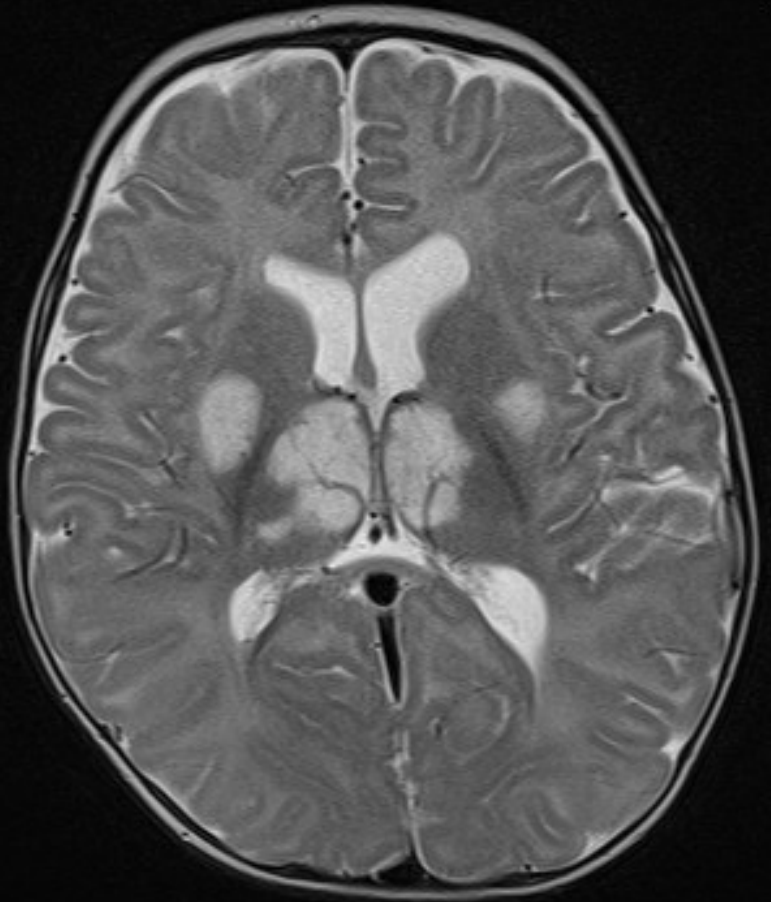

[PH]
Study Date: Study Time: MRN:

[L]

C554 W1145 


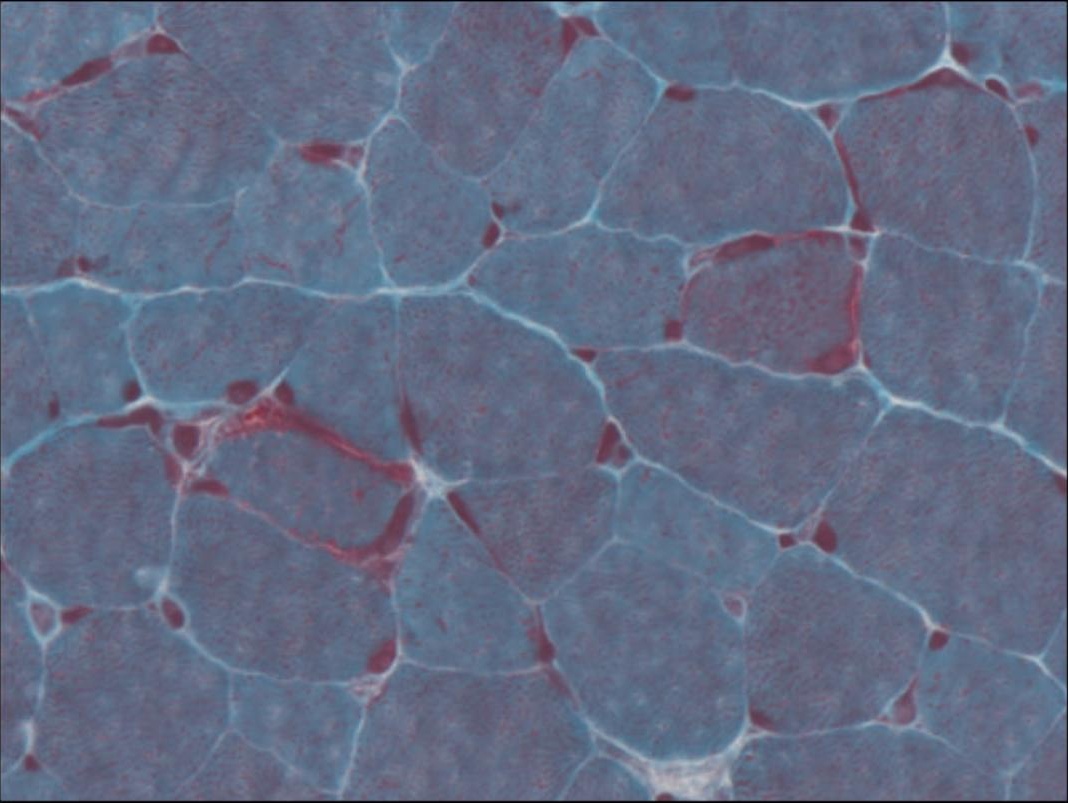




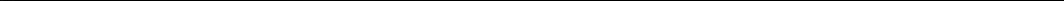


e

(9)

(1)

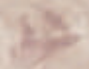

aty

$+$

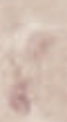

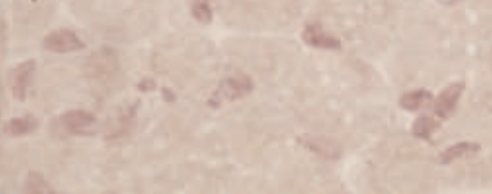

exis:

18 